\title{
Instructor Perceptions of Quality Learning in MOOCs They Teach
}

\author{
Jacob H. Askeroth and Jennifer C. Richardson \\ Purdue University
}

\begin{abstract}
Included in the discussions regarding the instructional and learning value of massive open online courses (MOOCs) is the question of whether MOOC learners gain much value, if any at all, and has been a continuing debate since MOOCs began. Skeptics argue that MOOCs lack academic rigor and are superficial, while proponents praise them as addressing important global issues of educational access and affordability, providing pathways to more substantial learning opportunities. An important viewpoint in this conversation that warrants consideration is that of the professors/instructors who teach MOOCs and how they perceive the quality of learning that takes place in their MOOCs. In this case study, we used semistructured qualitative interviews with three MOOC instructors in addition to course and document reviews to identify examples of their perceptions in practice. The findings from this case study suggest that instructors do believe that quality learning can take place within a MOOC and is often accomplished through social constructivism and self-regulated learning approaches. Discussions, dialogues, negotiations, and collaborations as well as learners accomplishing their intended goals in the course were all considered to be manifestations of quality learning in a MOOC. Implications of the findings for additional research and practice are also discussed.
\end{abstract}

Keywords: massive open online courses, MOOCs, social constructivism, self-regulated learning, online learning, case study

Askeroth, J.H., \& Richardson, J.C. (2019). Instructor perceptions of quality learning in MOOCs they teach. Online Learning, 23(4), 135-159. doi:10.24059/olj.v23i4.2043

\section{Instructor Perceptions of Quality Learning in MOOCs They Teach}

Enrollments in, and diversification of, online learning contexts continue to grow (Seaman, Allen, \& Seaman, 2018), especially as massive open online courses (commonly referred to as MOOCs) have begun to play a larger role in the online education industry (Palvia et al., 2018). MOOCs stem from a vision to provide free public access to education in large, open courses offered in an online format (Ferguson, Sharples, \& Beale, 2015), which intends to address important global issues, such as educational access and affordability (Evans \& Myrick, 2015; Ferguson \& Clow, 2015; Friedman, 2013). As an emerging online learning context, MOOCs offer unique learning experiences for the learner (Littlejohn, Hood, Milligan, \& Mustain, 2016), alter the role of the online instructor (Haavind \& Sistek-Chandler, 2015; Ross, Sinclair, Knox, Bayne, \& Macleod, 2014; Zheng, Wisniewski, Rosson, \& Carroll, 2016), and tend to attract learners with diverse interests and goals (Walji, Deacon, Small, \& Czerniewicz, 2016). Due to these referenced 
opportunities provided by MOOCs, many institutions and providers are finding new ways to utilize and package MOOCs as pathways toward degree programs and even offer full master's degrees on their platforms (Baker, Passmore, \& Mulligan, 2018; Kurzweil, 2018; Reich \& RuipérezValiente, 2019).

Ongoing discussions regarding the instructional and learning value of MOOCs vary among scholarly and practitioner arenas (Brahimi \& Sarirete, 2015; Czerniewicz, Deacon, Glover, \& Walji, 2017; Haggard, Wang, \& He, 2014; Honeychurch \& Draper, 2013). For example, some correlate the overall low completion rates to poor instructional quality (Onah, Sinclair, \& Boyatt, 2014), while others argue that course completion is an inaccurate indicator of MOOC success given the wide variety of reasons that bring learners to a MOOC (DeBoer, Ho, Stump, \& Breslow, 2014; Ho et al., 2014; Liu, Kang, \& McKelroy, 2015; Zelinski, Hicks, et al., 2017). Furthermore, some contend that instructional and learning quality are poor in most MOOCs (Margaryan, Bianco, \& Littlejohn, 2015), and yet others claim it is feasible that MOOCs meet the standards of quality set for other online courses (Lowenthal \& Hodges, 2015). These differing opinions on the uses for and direction of MOOCs warrant further discussion, yet there is a gap in the literature regarding the viewpoints of faculty and instructors of MOOCs (Evans \& Myrick, 2015; Lowenthal, Snelson, \& Perkins, 2018; Yengin, Karahoca, \& Karahoca, 2011).

An instructor's direct contact and experience with course content, instructional design, and the learners in their MOOCs can greatly contribute to relevant literature, scholarship, and practice. The scarcity of instructor perspectives creates a compelling need for this area of the literature to be developed (Deng, Benckendorff, \& Gannaway, 2017; Lowenthal et al., 2018). Thus, this case study explored the perceptions of MOOC instructors regarding quality learning in their courses, focusing particularly on learning through social interactions, or social constructivism.

\section{Review of Literature}

\section{Social Constructivism in MOOCs}

Social constructivism, or social learning, is an increasingly emerging topic in current MOOC research and will continue to be in future MOOC research, and it has become evident that learners prefer socialization in MOOCs (Gasevic, Kovanovic, Joksimovic, \& Siemens, 2014). Social constructivism places emphasis on the importance of culture and context (McMahon, 1997) and views meaningful - or quality - learning as a social process that occurs when learners engage in social activities (Kim, 2001; Lave \& Wenger, 1991; Vygotsky, 1978). More specifically, social constructivism focuses on how the environment and interactions with others, along with support and scaffolding in the instruction, can influence the individual learning process (Lave \& Wenger, 1991; Toven-Lindsey, Rhoads, \& Lozano, 2015). Also, social interactions are important in online learning contexts in terms of fostering "a sense of psychological connection that may lead to increased motivation and increased satisfaction with an educational experience" (Shearer, 2012, pp. 253-254). Thus, the principles of social constructivism - focusing on collaboration, dialogue, and social interaction among learners - are compatible with online learning and achievable through MOOCs (Toven-Lindsey et al., 2015), which can bring together learners of diverse backgrounds who "interact with others in the knowledge construction process" (Arbaugh \& Benbunan-Fich, 2006, p. 438). 
While MOOCs can provide and are providing educators with new ways to scale social learning within global and diverse groups, it is important to recognize that designing for learner engagement in a MOOC can be difficult given the scale and diversity of learners and motivations (Milligan, Littlejohn, \& Margaryan, 2013). Walji et al.'s (2016) case study of MOOCs identified important aspects of social constructivism afforded in MOOCs, which included teacher presence, social learning, and peer learning. These aspects were connected to high-quality learning in MOOCs. Social learning, in particular, provides positive learning outcomes: "learners ... benefit from engaging with others through conversations and interactions" (p. 215).

Toven-Lindsey et al. (2015) studied 24 university-level MOOCs from a range of disciplines and found that one third of them implemented or featured a "constructivist-group approach" activity - a dialogue on discussion boards, participation in organized discussion groups, live videoconferencing with the instructor, or peer-reviewed assignments. Their findings suggested that the "constructivist-group teaching approach encourages the highest level of collaboration and critical inquiry among participants" (p. 7) based on the higher level of participation and engagement in constructivist activities. These results, among other influences, are contributing to MOOCs and their platforms utilizing social constructivist approaches to foster quality learning.

\section{Instructor Perceptions of Quality Learning in MOOCs}

Research studies on learning in MOOCs focus heavily on understanding the outcomes and perspectives of the learners (Deng et al., 2017; Evans \& Myrick, 2015; Xing, 2019, Zheng et al., 2016), highlighting their experiences, challenges, patterns of engagement (Milligan et al., 2013), outcomes, and motivations for taking the MOOC (Breslow, Pritchard, DeBoer, Stump, Ho, \& Seaton, 2013; Emanuel et al., 2013; Liu et al., 2015; Park, Jung, \& Reeves, 2015; Walji et al., 2016; Zutshi, O'Hare, \& Rodafinos, 2013). General themes emerging from the literature include flexible learning design of MOOCs to accommodate the diverse needs and goals of learners (Park et al., 2015; Walji et al., 2016) and learner satisfaction (Liu et al., 2015). Fewer in number are the studies and articles that give voice to the perspectives of the instructors of the MOOCs (Czerniewicz et al., 2017; Lowenthal et al., 2018; Zelinski et al., 2017). For example, Veletsianos and Shepherdson (2016) reviewed the literature on MOOCs and found that of the 183 studies they reviewed, only $8.2 \%$ focused on topics that related to instructors and teaching.

Several studies in the literature to date have focused on MOOC instructors and do offer some helpful insights into their experience. These studies, however, focus on and articulate the experiences, motivations, and viewpoints of MOOC instructors in broad terms, highlighting the experiences and challenges of developing and teaching MOOCs (Haavind \& Sistek-Chandler, 2015; Najafi et al., 2015; Zelinski et al., 2017; Zheng et al., 2016) as well as the opportunities to try new pedagogical approaches in a new platform (Evans \& Myrick, 2015; Toven-Lindsey et al., 2015). Annaraud and Singh's (2017) study concluded that students and faculty have varying perceptions and enthusiasm regarding MOOCs; a potential cause of the disparity, they said, could have been the faculty members' deeper understanding of challenges to developing and teaching a MOOC. Another study by Haavind and Sistek-Chandler (2015) highlighted the struggles and challenges of a MOOC instructor, especially that of offering a personalized learning experience for the learner due to the large number of participants in MOOCs.

However, Lowenthal et al. (2018), using an explanatory mixed methods approach, surveyed a large number of previous MOOC instructors and then invited a smaller number from that sample to be interviewed from those who responded in the survey that they would be willing 
to teach a MOOC again. The researchers found that the majority of instructors believed that their own MOOCs provided high-quality learning experiences for learners. However, the same instructors thought that, overall, MOOCs would not be as good as face-to-face courses. Evans and Myrick's (2015) findings slightly differed in that the faculty member participants in their study "were mixed on the idea that MOOC students learned as well as students in face-to-face courses, perhaps showing how the novelty of the format increased apprehension about learning outcomes compared to online learning at large, where attitudes about student learning have grown more positive" (p. 308).

As MOOCs continue to proliferate and influence online education, understanding the value that they offer to institutions and to learners will be more and more important. Thus, augmenting the means through which the perspectives of MOOC instructors are shared will offer a valuable contribution to further research and scholarship as well as inform practice.

\section{Methods}

Using social constructivism (Kim, 2001) as the lens, the purpose of this exploratory case study was to determine instructors' perceptions of quality learning in MOOCs. Specifically, this study was guided by the following research questions:

1. What are MOOC instructors' perceptions of quality learning?

2. What factors do MOOC instructors believe influence or enable quality learning?

3. What aspects or affordances of MOOCs do MOOC instructors believe allow them to perceive quality learning?

4. How do instructors perceive social learning as influencing quality learning in a MOOC?

We utilized semistructured interviews with instructors as the primary source of data. Additionally, we used course document reviews as a secondary source to provide examples of their perceptions in practice as well as triangulation. Together these sources were developed into a multiple case study design, one based on exemplars as the basis of replication logic (Yin, 2014). With this type of multiple case study design it is customary to select the cases, conduct the case studies, write individual case reports, and draw cross-case conclusions (Yin, 2014). Given that this is an exploratory study, our analytic technique involved explanation building, with our goal being to develop themes and determine next steps in researching quality learning in MOOCs from a social-constructivist perspective (Yin, 2014).

\section{Context}

Access to participants (MOOC instructors) was possible through current working relationships with instructors who have taught at least one MOOC on our institution's MOOC partner's platform, FutureLearn. FutureLearn is based on social constructivism or social learning theory (Ferguson \& Clow, 2015; Walji et al., 2016). According to FutureLearn (2016), social learning "enables learners to form online cohorts and communities of practice that support and enrich their learning" (p. 14). FutureLearn's social learning platform leverages the power of learner communities, "where learners can make immediate use of their newly acquired skills by sharing their knowledge with their peers" (FutureLearn, n.d.). 
For each of these instructors, this was the first MOOC any of them had taught. Purposive sampling was used to identify and recruit MOOC instructors from this available pool. Specifically, our three participants were selected based on our criteria for being exemplars; their courses had higher than average scores in areas of total course enrollments, a higher than average number of learners who were actively engaged in the course, and/or a higher than average number of learners who opted to purchase a certificate of completion in the course (see Table 1).

Table 1 includes data that provides an additional depth to the MOOCs of the participating instructors and why they were selected as the case exemplars. Aside from basic information including the number of course runs, it also includes aspects such as total number and average number of active learners. FutureLearn defines "active learners" as learners who have completed at least one step at any time in any course week. Information related to certificate purchases is also included; in this case, in order to purchase a certificate of completion in the course, a learner is required to complete a minimum of $51 \%$ of the course activities and pay a minimal fee for a printed certificate of completion. These MOOCs were selected because they had higher averages in one or more of these areas than the institution's MOOC average, which are also provided.

Table 1

Comparison of Participant MOOCs and Institutional MOOC Average Based on Enrollment and Evidence of Active Participation

\begin{tabular}{|c|c|c|c|c|c|c|c|c|}
\hline MOOC & $\begin{array}{l}\text { Number } \\
\text { of runs }\end{array}$ & $\begin{array}{l}\text { Total } \\
\text { enrollment }\end{array}$ & $\begin{array}{l}\text { Total } \\
\text { active } \\
\text { learners }\end{array}$ & $\begin{array}{l}\text { Total } \\
\text { certificates } \\
\text { purchased }\end{array}$ & $\begin{array}{l}\text { Average } \\
\text { total } \\
\text { enrollme } \\
\text { nt across } \\
\text { runs }\end{array}$ & $\begin{array}{l}\text { Average } \\
\text { active } \\
\text { learners } \\
\text { across } \\
\text { runs }\end{array}$ & $\begin{array}{l}\text { Average } \\
\text { total } \\
\text { certificates } \\
\text { purchased } \\
\text { across runs }\end{array}$ & $\begin{array}{l}\text { Average } \\
\text { certificate } \\
\text { purchase } \\
\text { percent of } \\
\text { total } \\
\text { enrollment }\end{array}$ \\
\hline $\begin{array}{l}\text { Institution } \\
\text { MOOC } \\
\text { Average }\end{array}$ & & & & & 2,681 & 1,167 & 29 & $1.07 \%$ \\
\hline $\begin{array}{l}\text { Laura's } \\
\text { Course }\end{array}$ & 6 & 25,626 & 14,048 & 111 & 4,271 & 2,341 & 19 & $0.45 \%$ \\
\hline $\begin{array}{l}\text { Jane's } \\
\text { Course }\end{array}$ & 3 & 7,183 & 2,877 & 105 & 2,394 & 959 & 35 & $1.46 \%$ \\
\hline $\begin{array}{l}\text { Dave's } \\
\text { Course } 1\end{array}$ & 4 & 8,240 & 3,176 & 89 & 2,060 & 794 & 30 & $1.18 \%$ \\
\hline $\begin{array}{l}\text { Dave's } \\
\text { Course } 2\end{array}$ & 6 & 10,332 & 4,652 & 240 & 1,722 & 775 & 48 & $2.35 \%$ \\
\hline
\end{tabular}

\section{Procedures and Data Analysis}

To collect data for the study, we determined that semistructured interviews would be most appropriate in answering the stated research questions because they are "sufficiently structured to address specific topics related to the phenomenon of study, while leaving space for participants to offer new meanings to the study focus" (Galletta, 2013, p. 24). Semistructured interviews afford the ability to create consistency across multiple interviews and provide the researcher the opportunity to probe and ask clarifying questions. Moreover, the semistructured interviews allow important insights to be gained by developing an authentic narrative regarding the experience of MOOC instructors and what perceptions they have toward the learning in MOOCs. 
The interviews all followed the same semistructured protocol (see Appendix A) with each instance having its own unique variation depending on the direction of the conversation between the participant and the first author (Galletta, 2013). The questions in the interview protocol focused on aspects of defining quality learning, social learning in MOOCs, MOOC affordances that influence learning, and overall experience teaching MOOCs. Each interview was approximately 60 minutes in length and recorded via an audio recording application. Each interview was then uploaded and stored in a secure, password-protected account and transcribed verbatim.

Transcripts from the interviews were analyzed through a combination of predefined (a priori) codes (see Appendix B) and emergent codes to categorize, summarize, and condense data (Saldana, 2013) into to themes. The a priori codes were developed and identified based on relevant literature on MOOCs and the selected theoretical framework, social constructivism. After coding, a streamlined codes-to-theory model (Saldana, 2013) was used to organize the coded segments into categories. Finally, the categories were reviewed and analyzed again to further identify and condense categories into themes based on conceptual overlap and then into broader themes that aligned with principles of social constructivism. Trends and patterns from the data were then developed dependent on the extent to which the themes answered the research questions.

The course document review looked specifically at the discussion threads of the MOOCs taught by participants. Documents, as defined by Yin (2014), are stable and can be viewed repeatedly, are unobtrusive, and can be specific or broad. As Yin (2014) explains, "the most important use of documents is to corroborate and augment evidence from other sources" (p. 107). The threads were reviewed to look for examples of potential social learning taking place; these were revealed through instances of interactions between instructors and students.

To help establish trustworthiness throughout this study, several steps were taken as per Lincoln and Guba's (1985) criteria. For credibility, we triangulated the data, and member checking was conducted following the data analysis stage to allow participants to review and confirm our data and interpretations. Transferability was addressed through purposive sampling. An external audit of the research by faculty experts $(N=3)$ served to help with dependability. Finally, confirmability was established by ensuring research protocols were based in the literature.

\section{Results}

The following section presents three individual cases, one per each participating MOOC instructor, and will be outlined according to the previously stated research questions. Pseudonyms have been used in place of participants' names. Each case will include a brief description of the course, relevant responses from the semistructured interviews with each instructor, and examples directly from their courses

\section{Laura}

Laura's MOOC was a part of the inaugural group of four FutureLearn courses launched by this institution in April 2017. This was Laura's first experience developing and teaching an online course. Support for the course development was provided to Laura in the form of an instructional designer and video production specialist to get the course ready for its first and subsequent runs on the FutureLearn platform. Since its launch, her MOOC has had six individual runs. Moreover, Laura's MOOC has had the highest enrollment in a single run of any of the institution's FutureLearn courses so far (see Table 1). 
What factors do MOOC instructors believe influence or enable quality learning? In addition to this being the first MOOC she had ever taught, Laura's MOOC was also the first experience she had with teaching online. She had initial concerns about how learners in the MOOC would contribute to discussions under anonymous Internet profiles, though many learners used their full first name. However, she noticed that this aspect of a MOOC tended to make many learners more open to comment freely in discussions and share ideas in the discussion threads throughout the course, especially for students who might otherwise feel muted or less inclined to participate in a traditional classroom.

What aspects or affordances of MOOCs do MOOC instructors believe allow them to perceive quality learning? To Laura, the online discussion boards in her MOOC seem to make the learning more apparent because learners interact with one another by articulating their own independent thoughts, which can be an indicator of their conceptual knowledge and understanding of the content (Arbaugh \& Benbunan-Finch, 2006). Additionally, Laura commented that the sharing of a wide variety of learner perspectives contributed to her being able to verify that learning was occurring: "Being able to see early principles and concepts of what I am teaching come out in students' comments in a bigger variety is a verification of learning." Laura also mentioned that the discussion features on the MOOC platform, such as giving learners the ability to immediately read through the comments of others or post their own thoughts alongside each course step, allowed learners to collaborate with one another and that it contributed to how learners looked at the content presented by the instructor. They were able to share variety of insights that allowed them to negotiate meaning for themselves and others.

How do instructors perceive social learning as influencing quality learning in a MOOC? Laura's perception of how social learning within her MOOC affected the quality of learning included learners' comments prompting discussions of additional, unplanned topics: "Some people will give each other references and links to other resources and then we talked about whether those resources are valid in the discussion." Figure 1 is an example of such an occasion, in which learners (all names have been changed to protect identity) in Laura's course shared or suggested additional resources with one another in one of the discussion threads. Laura was able to participate in the conversation and further facilitate the social learning of the course. 


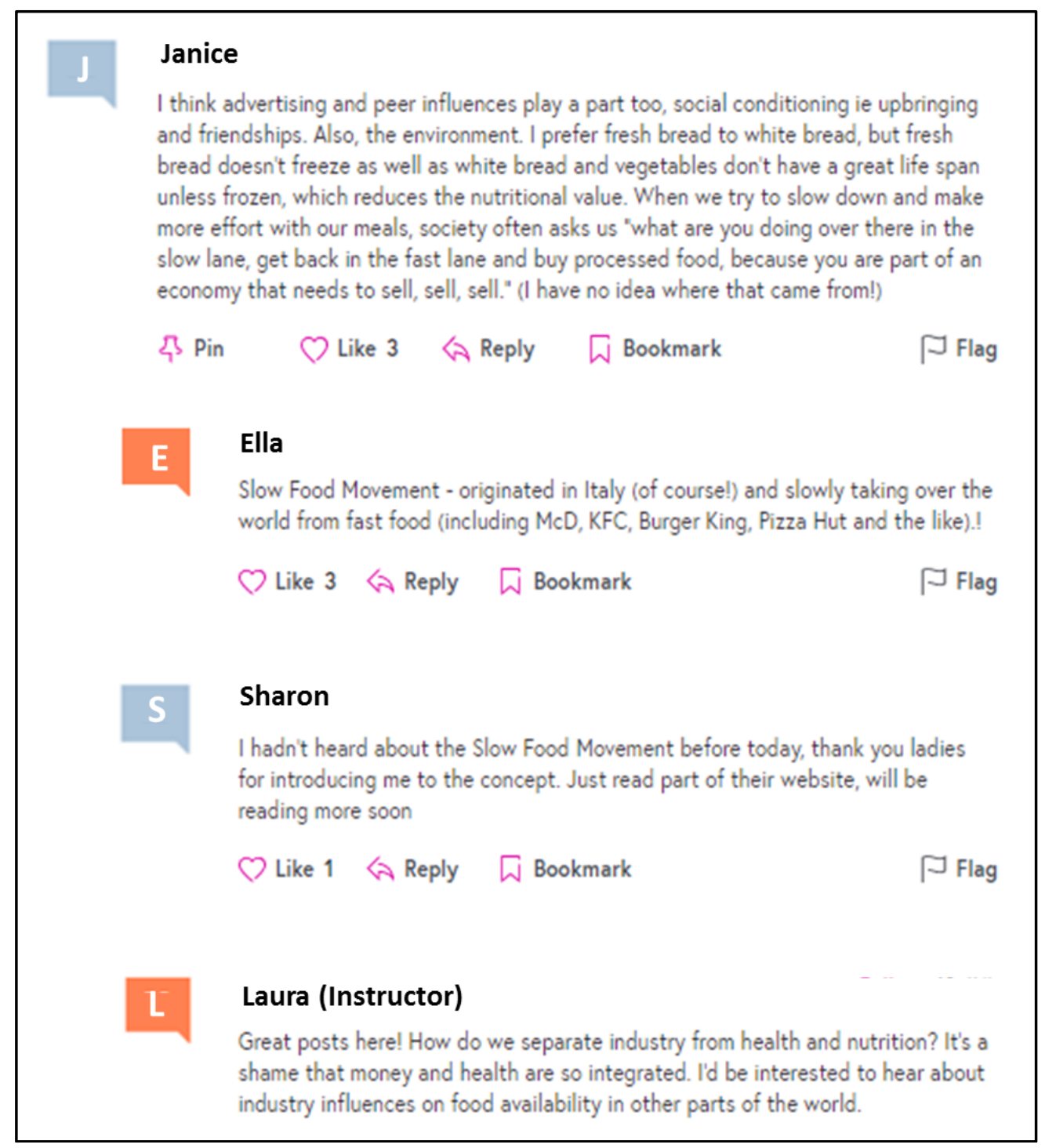

Figure 1. Example of discussion thread demonstrating shared resources from Laura's MOOC.

Laura additionally remarked on how social interaction in her MOOC has influenced her own learning: "I've actually learned from the people that participate because of all the different perspectives and backgrounds. There's been ... things that have happened historically that have played into how food culture has evolved so it's been interesting to get a different history or background and that's been cool."

Jane

Jane's MOOC on the FutureLearn platform first launched in October 2017 and has since had three runs. While this was her first time teaching a MOOC, Jane had previous experience in teaching online courses. To develop her MOOC, Jane was able to work with the same instructional designer with whom she had worked on her previous online course. She also worked with a video production specialist to script, record, and edit videos for her MOOC. 
What factors do MOOC instructors believe influence or enable quality learning? For Jane, the high number of enrollments typical in MOOCs as well as the group of learners that come with diverse backgrounds (e.g., interests, goals, and perspectives) were positive features that encouraged social learning that therefore affected the quality learning. She said, "I thought there would be more retired people but there are not as many. It was very spread out among ages of those who wanted to learn. It surprisingly included people of all ages." The wide range of learner perspectives, Jane continued, also prompted other learners to "think about things in a different way and it allows them (the learners) to express what they're thinking about, what they're feeling about. There has been some disagreements about ideas, which has been interesting, but they work it out." Figure 2 depicts an excerpt from a discussion thread from one of the runs of Jane's MOOC. Again, all names of learners have been changed.

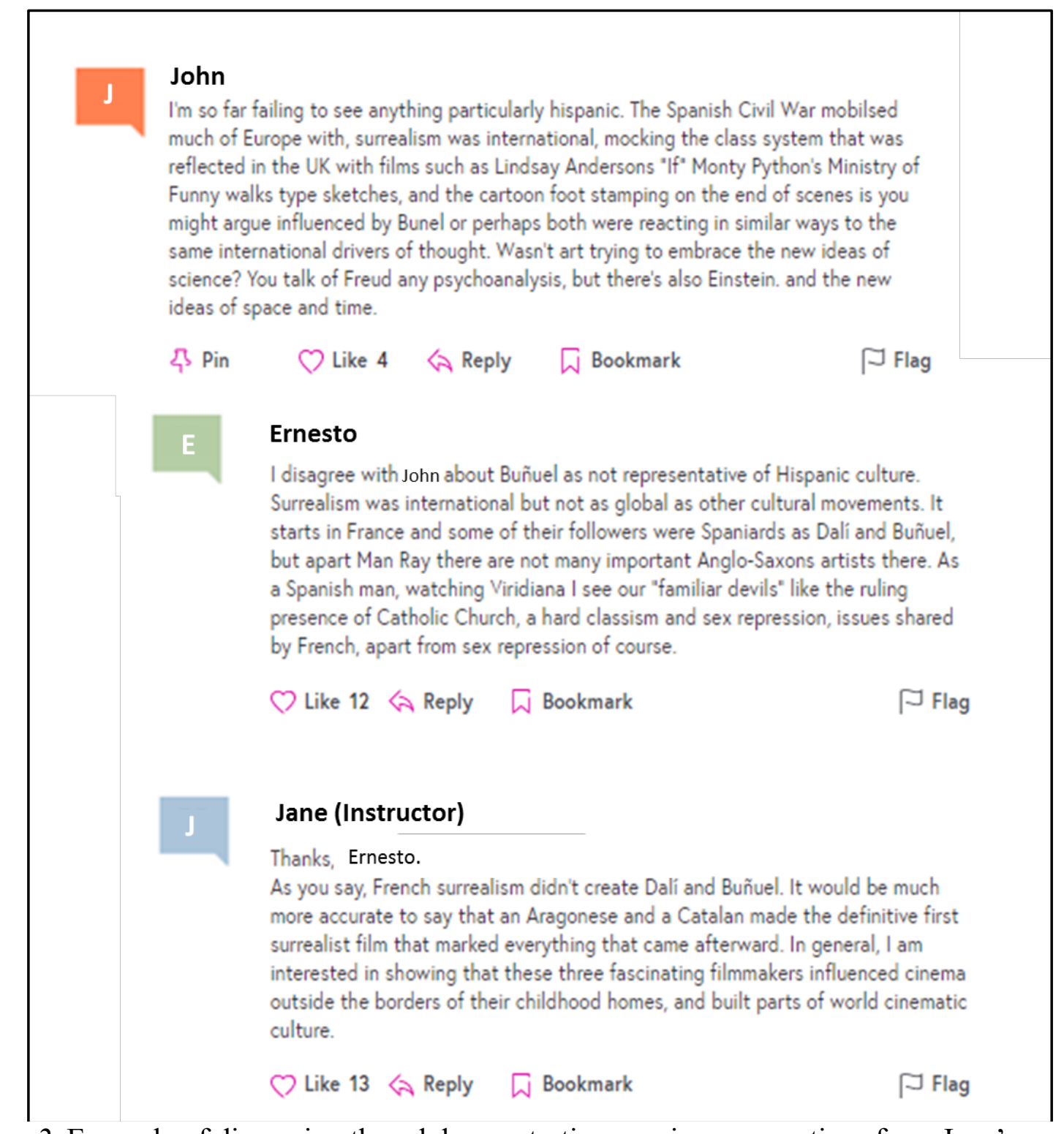

Figure 2. Example of discussion thread demonstrating varying perspectives from Jane's course. 
What aspects or affordances of MOOCs do MOOC instructors believe allow them to perceive quality learning? Jane also believed that the structure of her MOOC, particularly the discussions that were connected to each activity, allowed her to perceive — or in her words, evaluatelearning:

Each week they had articles to read and videos that they had to watch, and ... on every one of these there was a discussion. So basically, they (the learners) discuss whatever they wanted about the question. Sometimes there are very specific questions with a quiz that leads into a final discussion. I guess you could say those were the ways they were evaluated. There was one quiz each week and then there were discussions all along the way.

Jane concluded that learning was taking place often based on the number of comments by learners in the discussions. In addition to this, she also looked at the number of views of course videos. She also interpreted these two analytics as an indicator of how her learners behaved or adjusted their engagement based on their individual interests and goals. She said,

[Participation in discussions] was surprisingly high because people did it because they wanted to. If they didn't think something was interesting I could see that discussion participation was low. There were also some videos that got very low views and I could see that the subject was not very interesting to the students. And they did it for no other reward than because they were interested.

Intrinsic motivation to learn was very salient for Jane that has made teaching a MOOC a rewarding experience.

\section{Dave}

Like Jane's experience, Dave's MOOC teaching was not his first experience in developing and teaching in an online format. Like the other participants, Dave worked with an instructional designer and video production specialist for the development of his MOOCs on FutureLearn's platform. To date, Dave has been the institution's most prolific instructor on the FutureLearn platform, having taught multiple MOOCs with multiple runs. Additionally, one of his courses (Dave Course 2; see Table 1) has had the highest average percentage of its learners purchasing a certificate of completion at its conclusion.

How do instructors perceive social learning as influencing quality learning in a MOOC? During the interview, Dave readily recognized and pointed to the social learning affordances of MOOCs and considered them to be unique and as having a positive influence on learners:

I think the unique thing with the MOOCs is the social learning and the fact that there are students from all over the world with very different perspectives. I have learners that are 70 and I have learners that are 18, and when they're participating and sharing their ideas with one another I think that really contributes to how everyone's looking at the information and helps them grow.

To this end, Dave saw that his own engagement in discussions not only affected the learning of learners but his own as well. He said,

I really tried to get into more of the discussion with the learners this last time in the course. And I feel like I was energized by it and I would assume the learners maybe felt energized as well if they were participating.

Figure 3 depicts an excerpt from a discussion thread from one of the runs of Dave's MOOC. All names of learners have been changed. 


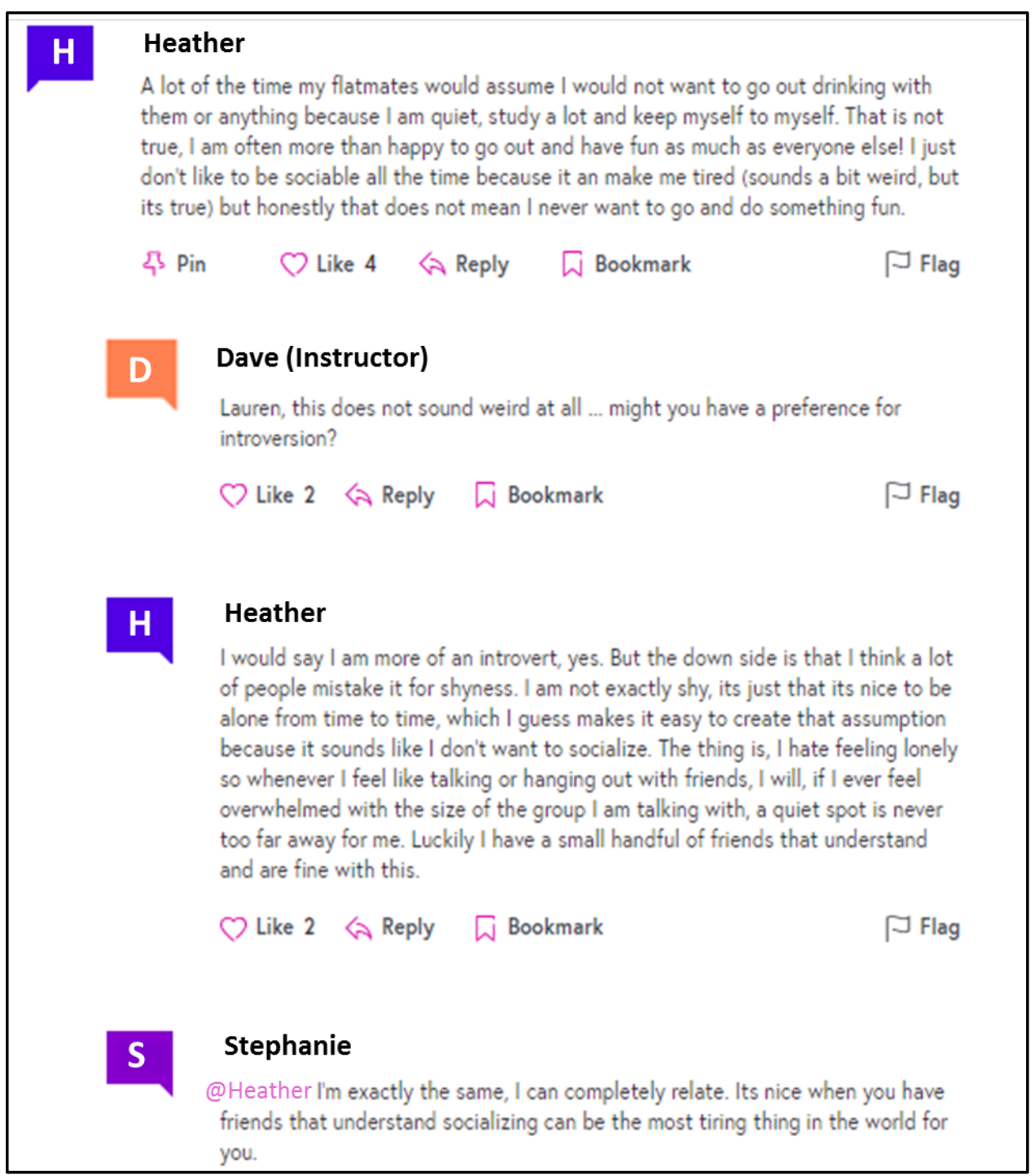

Figure 3. Example of discussion thread demonstrating differing perspectives from Dave's course.

What are MOOC instructors' perceptions of quality learning? What aspects or affordances of MOOCs do MOOC instructors believe allow them to perceive quality learning? To Dave, quality learning is linked to a learner's autonomy to self-direct or regulate his or her own learning. One way Dave defines quality learning in a MOOC is whether the learner has gotten out of the course what they had initially intended. He said,

I think the MOOCs allow students to determine how much they're going to learn and I think a traditional class, whether a hybrid, blended, or a professor standing up lecturing them, giving five exams during the semester, is only forcing students to learn whatever level they (the faculty) want in terms of passing the course, earning an "A" or a "C." I don't consider that learning. I consider real learning to be allowing the student to get what they want to get out of the course. I think that can happen in a traditional class and I think it happens in a MOOC. 


\section{Cross-Case Synthesis}

As previously mentioned, the authors utilized a cross-case synthesis after each individual case study was conducted. This was done in an effort to help provide a framework for the explanation-building process. This included an inductive process through which three themes emerged: (1) instructors perceive that social interactions in MOOCs can foster quality and meaningful learning experiences for both learners and instructors, (2) instructors perceive that learner goals and interests can ultimately influence their participation and learning in MOOCs, and (3) instructors perceive social learning in MOOCs through discussion boards. These three themes do share some overlap, which may or may not be apparent at times.

Social interactions in MOOCs foster quality learning. Social constructivist principles were among the most identified characteristics that demonstrated quality learning in a MOOC by the instructors participating in this case study. This was attributed to the unique features often inherently afforded by MOOCs to bring a wide range of diverse learners into one space. Moreover, the FutureLearn platform in particular allows for frequent and intuitive social interaction, in that each step or activity provides opportunities for learners to comment on and share what they are learning with peers along the way (FutureLearn, n.d.).

Each instructor recognized that inherent features of the MOOCs provided opportunities for both themselves and learners to experience and engage in social learning opportunities. The high number of enrollments typical in MOOCs as well as the group of learners that come from diverse backgrounds (e.g., interests, goals, and perspectives) were seen as positive features that encourage social learning that therefore impacted the quality learning available to learners. Multiple instructors commented on the role that social learning played in their own learning and the positive experience they had by way of interaction with learners within their MOOC.

The opportunity for social interaction among a large, diverse group afforded to both learners and instructors was viewed as an effective and valuable means to provide quality learning within these instructors' MOOCs. In addition to social interaction, the goals of learners (also diverse) can also influence the learning that occurs in MOOCs.

Learner goals can influence learning in MOOCs. As mentioned, the primary framework for this case study was social constructivism. However, unexpectedly a theme that emerged that could have also been used as another relevant framework for this case study was self-regulated learning (SRL). Many view SRL to be integral to learner behaviors in MOOCS, and many investigative studies that focus on self-regulated learning appear in MOOC literature (Lee, Watson, \& Watson, 2017), with reasons being that a wide variety of learners enroll in MOOCs with varying and specific purposes or goals as to what they would like to obtain from the course. Furthermore, SRL provides some insight into learner behaviors and motivation (Kizilcec, PérezSanagustín, \& Maldonado, 2017).

Two of the participants spoke frequently about how a MOOC allows learners to come into the course and participate in only those areas or aspects that are of interest to them or fulfill their individual purpose for taking the course. Reponses from instructors on this topic seem to align with the first and third phases of Pintrich's (2000) model on self-regulated learning, which are goal setting and controlling and regulating the task, context, and self, respectively.

In Jane's MOOC, she noticed that there were some activities and videos in her MOOC that showed lower numbers of learners viewing the videos and lower accompanying discussion board 
participation on the given topic of the video or activity. However, some learners did watch the videos to the end and participate in the discussion prompted by the specific video. This might strongly suggest that SRL affordances in MOOCs, or the opportunity for a learner to engage in what is most relevant to them, can "positively affect a sense of academic achievement, as well as motivation and learner behaviours," (Lee et al., 2017, p. 31). Similar to social learning, one way through which these MOOC instructors perceived or observed SRL in their MOOCs was through interactions on discussion boards.

Instructors perceive social learning through discussion boards. The instructors in this case study all remarked how participating in and reading the discussion boards allowed them to get a sense of the learning that was taking place in their MOOC. In particular, discussion boards gave these instructors insights into how learners were collaborating with one another, negotiating meaning, making connections with different areas of knowledge, and learning new perspectives from a diverse group of learners. To multiple instructors, the online discussion boards in their MOOCs, if designed well, seemed to provide a means through which learning could be perceived, because learners interact with one another by articulating their thoughts, which can be an indicator of their conceptual knowledge and understanding of the content (Arbaugh, \& Benbunan-Finch, 2006). The discussion board features on the FutureLearn platform were also viewed to encourage and provide opportunity for social learning. All three of these participants also made a number of comments that suggest that social constructivism is a natural and inherent feature of MOOCs.

In summary, there were a number of similarities in each interview that informed the themes that emerged in the data analysis. Table 2 maps and illustrates the intersection of research questions and the main themes that emerged. Overall, each participant recognized that while there are certain challenges to verifying learning in MOOCs, such as scale, MOOCs that provide opportunities for learners to interact with peers and the instructor foster quality learning. Their perceptions of quality learning heavily involved the social interaction among a large, diverse group of learners common to MOOCs within the discussion boards on the course platform but was not solely limited to it. In addition to social interaction, individual learner goals and interests and their effect on learner engagement emerged as a theme; two instructors also perceived quality learning as entailing a learner achieving their intended goal in the course. 
Table 2

Intersection of Research Questions and Main Themes

\begin{tabular}{llll}
\hline Research questions & $\begin{array}{l}\text { Social interactions in } \\
\text { MOOCs foster quality } \\
\text { learning }\end{array}$ & $\begin{array}{l}\text { Main Themes } \\
\text { influence learning in } \\
\text { MOOCs }\end{array}$ & $\begin{array}{l}\text { Instructors perceive social } \\
\text { learning through discussion } \\
\text { boards in MOOCs }\end{array}$ \\
\hline $\begin{array}{l}\text { RQ1 - What are MOOC } \\
\text { instructors' perceptions of } \\
\text { quality learning? }\end{array}$ & $\mathrm{X}$ & $\mathrm{X}$ & \\
RQ2 - What factors do & & & $\mathrm{X}$ \\
$\begin{array}{l}\text { MOOC instructors } \\
\text { believe influence or } \\
\text { enable quality learning? }\end{array}$ & & & \\
$\begin{array}{l}\text { RQ3 - What aspects or } \\
\text { affordances of MOOCs } \\
\text { do MOOC instructors } \\
\text { believe allow them to } \\
\text { perceive quality learning? }\end{array}$ & $\mathrm{X}$ & \\
RQ4 - How do instructors \\
perceive social learning as \\
$\begin{array}{l}\text { influencing quality } \\
\text { learning in MOOCs? }\end{array}$
\end{tabular}

\section{Discussion}

This case study explored instructor perceptions of quality learning in MOOCs. There is still no universal agreement on many MOOC-related issues, including their rightful purpose and their effectiveness in offering meaningful or quality learning experiences (Evans \& Myrick, 2015). The main themes that emerged in this case study contribute to discussions on how MOOCs can be used - despite their intended purpose at times - to foster quality learning for people from diverse backgrounds, experiences, and learning goals. The instructors' responses aligned the four research questions of this case study, their perceptions being that quality learning can and does occur in these courses, for both learner and instructor, largely through social learning constructivist components, such as dialogue and discussion, peer interaction, negotiating meaning, collaboration, and peer teaching.

Though similar studies in the literature have helped inform both further scholarship and practice, instructors and institutions consider the reasons for and challenges of developing and teaching MOOCs, this case study took a unique approach to specifically explore the faculty perceptions of learning through the lens of social constructivism. Social constructivism/social learning continues to emerge as a key topic in current MOOC research and will continue to do so in future MOOC research (Gasevic et al., 2014), and the unique different perspectives regarding how instructors think about and view their MOOCs and the extent of their effectiveness in fostering meaningful, quality learning opportunities supports the growing interest in these topics. Moreover, this additional understanding of how instructors perceive quality learning occurring in MOOCs can reinforce and inform instructional design (Najafi et al., 2015) of MOOCs to leverage the opportunities for learners to achieve their learning goals via collaborative, social learning on a 
global scale. The emergent themes from this case study can also contribute to a broader framework for evaluating the effectiveness of a MOOC (Zelinski et al., 2017).

In addition to social constructivism or social learning, these instructors also perceived selfregulated learning to be an influential factor to the quality learning in a MOOC, which is consistent with the literature (Lee et al., 2017). More specifically, the responses of these instructors aligned with phases of Pintrich's (2000) model of self-regulated learning in the forms of goal setting and regulation of participation in specific learning tasks. When learners got out of the MOOC what was most important to them, whatever it may have been, these instructors considered it to be a success, though there are limitations of MOOC platforms that inhibit instructors from assessing what the diverse goals of learners are (Douglas, Zielinski, Merzdorf, Diefes-Dux, \& Bermel, 2019).

The MOOCs included in the case study were all what would be termed cMOOCs, which are heavily based in social constructivist learning design and differ from xMOOCs. Therefore, the instructors who developed and taught these courses all perceived that social interactions and learning played a significant role regarding how learners experienced quality learning in their MOOCs. Without this key component or feature, these instructors say that they would have been left to only utilizing multiple-choice quizzes and other automated assessment tools. These instructors appeared to consider the social learning outcomes to be of greater value in the MOOCs because they took advantage of the large and diverse learner population that enabled learners to connect with and learn from a wide range of individuals (Kop, 2011). It is interesting to compare this case study to Haavind and Sistek-Chandler's (2015) case study that concluded that whether in an cMOOC (focused on social interaction and collaboration) or an XMOOC (primarily using videobased lectures), the role of the instructor is the relatively the same, and real-time engagement with the learners has little effect on the learning that takes place. The study in this paper did not focus heavily on the instructor's role in and effect of interaction with the learners in the MOOC, which suggests that further inquiry on this subject could be beneficial.

Each instructor commented on how teaching their MOOC(s) changed their perspective on how they defined quality learning in terms of what is possible in online learning environments and, more specifically, MOOCs. This is similar to findings by Evan and Myrick (2015) that describe favorable attitudinal changes toward online learning in general, resulting in and increased acceptance and improved perspectives on the purpose of MOOCs.

\section{Limitations}

As with any study, various challenges or limitations exist that are worth considering as conclusions are developed and future research considered. For example, the instructors who participated in this case study utilized and were familiar with only one MOOC platform that is heavily based in social learning theory, and this might therefore skew their perspective. Moreover, participants' specific discipline or course topic may have influenced how they perceived quality learning in a MOOC. Additionally, this study had a small sample size of only three participants, all of whom are from a single institution, as were the instructional designers they worked with, meaning that a particular institutional design process or framework was potentially used, thereby not allowing for variability. 


\section{Conclusion}

With little current literature that focuses on instructor perceptions in this specific topic, the findings from this case study help to fill a current gap in the MOOC literature. Furthermore, highlighting more viewpoints of instructors of MOOCs can be beneficial to the ongoing research, practice, and discussion regarding MOOCs as viable learning opportunities.

This case study merely scratches the service in exploring and understanding instructor perceptions of quality learning in MOOCs. Further research should follow similar approaches to, for example, compare instructor perceptions of quality learning through social interaction with quantitative data of the levels or patterns of learner engagement (Milligan et al., 2013) within social learning settings, such as MOOC discussion boards. It would also be insightful to include a larger sample to see if the perceptions expressed in this case study have broader application. Finally, it would be important and interesting in future research studies to also include other types of MOOC (e.g., xMOOCs) and MOOC instructors who do not employ social learning theories as a basis for their platforms or course instructional design to see whether they have similar perceptions of quality learning. Additionally, increased understanding of faculty perceptions toward MOOC learning can help inform the instructional design of MOOCs and how learners can learn in these unique online environments. Further research on this and other MOOC-related topics is important and needed because MOOCs can offer increased access to education and can, according to perceptions held by the instructors in this case study, provide meaningful learning opportunities and social connections for people all around the world.

\section{Acknowledgments}

We appreciate the willingness of the MOOC instructors to participate in the interviews in this case study and offer their candid responses. 


\section{References}

Annaraud, K., \& Singh, D. (2017). Perceptions of hospitality faculty and students of massive open online courses (MOOCs). Journal of Hospitality \& Tourism Education, 29(2), 8290. doi:10.1080/10963758.2017.1297714

Arbaugh, J. B., \& Benbunan-Finch, R. (2006). An investigation of epistemological and social dimensions of teaching in online learning environments. Academy of Management Learning \& Education, 5(4), 435-447. doi:10.5465/amle.2006.23473204

Baker, R., Passmore, D. L., \& Mulligan, B. M. (2018). Inclusivity instead of exclusivity: The role of MOOCs for college credit. In Enhancing education through open degree programs and prior learning assessment (pp. 109-127). IGI Global. doi:10.4018/978-15225-5255-0.ch00

Brahimi, T., \& Sarirete, A. (2015). Learning outside the classroom through MOOCs. Computers in Human Behavior, 51, 604-609. doi:10.1016/j.chb.2015.03.013

Breslow, L., Pritchard, D. E., DeBoer, J., Stump, G. S., Ho, A. D., \& Seaton, D. T. (2013). Studying learning in the worldwide classroom research into edX's first MOOC. Research \& Practice in Assessment, 8, 13-25.

Corbin, J. M., \& Strauss, A. (1990). Grounded theory research: Procedures, canons, and evaluative criteria. Qualitative sociology, 13(1), 3-21. doi:10.1007/BF00988593

Creswell, J. W. (2012). Educational research: Planning, conducting, and evaluating quantitative and qualitative research (4th ed.). Upper Saddle River, NJ: Pearson.

Czerniewicz, L., Deacon, A., Glover, M., \& Walji, S. (2017). MOOC-making and open educational practices. Journal of Computing in Higher Education, 29(1), 81-97. doi:10.1007/s12528-016-9128-7

Daniel, J. (2012). Making sense of MOOCs: Musings in a maze of myth, paradox and possibility. Journal of Interactive Media in Education, 2012(3). doi:10.5334/2012-18

DeBoer, J., Ho, A. D., Stump, G. S., \& Breslow, L. (2014). Changing 'course': Reconceptualizing educational variables for massive open online courses. Educational Researcher, 43(2), 74-84. doi:10.3102/0013189X14523038

Deng, R., Benckendorff, P., \& Gannaway, D. (2017, May). Understanding learning and teaching in MOOCs from the perspectives of students and instructors: A review of literature from 2014 to 2016. In European Conference on Massive Open Online Courses, 176-181. Springer, Cham. doi:10.1007/978-3-319-59044-8_20

Douglas, K., Zielinski, M., Merzdorf, H., Diefes-Dux, H., \& Bermel, P. (2019). Meaningful learner information for MOOC instructors examined through a contextualized evaluation framework. The International Review of Research in Open and Distributed Learning, 20(1). Retrieved from http://www.irrodl.org/index.php/irrodl/article/view/3717

Emanuel, E., Christensen, G., Steinmetz, A., Alcorn, B., Bennett, A., \& Woods, D. (2013). Online education: MOOCs taken by educated few. Nature, 503, 346. doi:10.1038/ $503342 \mathrm{a}$ 
Evans, S., \& Myrick, J. G. (2015). How MOOC instructors view the pedagogy and purposes of massive open online courses. Distance Education, 36(3), 295-311. doi:10.1080/01587919.2015.1081736

Ferguson, R., \& Clow, D. (2015). Examining engagement: Analysing learner subpopulations in massive open online courses (MOOCs). In Proceedings of the Fifth International Conference on Learning Analytics and Knowledge, 51-58. ACM. doi:10.1145/2723576.2723606

Ferguson, R., Sharples, M., \& Beale, R. (2015). MOOCs 2030: A future for massive open online learning. Retrieved from http://oro.open.ac.uk/43541/3/MOOCs\%202030\%20revised.pdf

Fernandez, J. V., \& Webster, S. (2014). From OCW to MOOC: Deployment of OERs in a massive open online course. The experience of Universidad Carlos III de Madrid (UC3M). Open Praxis, 6(2), 145-158. doi:10.5944/openpraxis.6.2.115

Friedman, T. (2013, January 27). Revolution hits the universities. The New York Times. Retrieved from http://www.nytimes.com/2013/01/27/opinion/sunday/friedmanrevolutionhits-the-universities.html

FutureLearn (n.d.). Learning on FutureLearn: An effective way to learn. Retrieved from https://www.futurelearn.com/using-futurelearn/why-it-works

FutureLearn. (2016). The future of learning in the workplace: The transformative power of collaborative social learning. Retrieved from https://ugc.futurelearn.com/other_assets/workplace-learning/the-future-of-learning-inthe-workplace.pdf

Galletta, A. (2013). Mastering the semistructured interview and beyond: From research design to analysis and publication. NYU press. doi:0.18574/nyu/9780814732939.001.0001

Gasevic, D., Kovanovic, V., Joksimovic, S., \& Siemens, G. (2014). Where is research on massive open online courses headed? A data analysis of the MOOC Research Initiative. The International Review of Research in Open and Distributed Learning, 15(5), 134-176. doi:10.19173/irrodl.v15i5.1954

Gast, A. (2013). Current trends in adult degree programs: How public universities respond to the needs of adult learners. New Directions for Adult and Continuing Education, 2013(140), 17-25. doi:10.1002/ace.20070

Haavind, S., \& Sistek-Chandler, C. (2015). The emergent role of the MOOC instructor: A qualitative study of trends toward improving future practice. International Journal on Elearning, 14(3), 331-350. doi:10.1016/J.edurev.2014.05.001

Haggard, S., Wang, B. H., \& He, X. L. (2014). The MOOC is maturing [J]. Educational Research, 5(412), 92-112 doi:10.12973/eurasia.2017.01056a

Herrington, J., \& Oliver, R. (1999). Using situated learning and multimedia to investigate higherorder thinking. Journal of Interactive Learning Research, 10(1), 3-24. Retrieved from http://researchrepository.murdoch.edu.au/id/eprint/6962/1/using_situated_learning.pdf 
Ho, A., Reich, J., Nesterko, S., Seaton, D., Mullaney, T., Waldo, J., \& Chuang, I. (2014). HarvardX and MITx: The first year of open online courses, Fall 2012-Summer 2013 (HarvardX and MITx Working Paper No. 1). Retrieved from http://dspace.mit.edu/bitstream/handle/1721.1/96649/SSRN-id2381263.pdf;sequence=1

Honeychurch, S., \& Draper, S. (2013). A first briefing on MOOCs. Glasgow: The University of Glasgow. Retrieved from http://eprints.gla.ac.uk/93069/1/93069.pdf

Kelly, A. P. (2014). Disruptor, distracter, or what? A policymaker's guide to massive open online courses (MOOCs). Bellwether Education Partners. Retrieved from https://files.eric.ed.gov/fulltext/ED553715.pdf

Kim, B. (2001). Social constructivism. Emerging perspectives on learning, teaching, and technology, 1(1), 16.

Kizilcec, R. F., Pérez-Sanagustín, M., \& Maldonado, J. J. (2017). Self-regulated learning strategies predict learner behavior and goal attainment in massive open online courses. Computers \& Education, 104, 18-33. doi:10.1016/j.compedu.2016.10.001

Kop, R. (2011). The challenges to connectivist learning on open online networks: Learning experiences during a massive open online course. The International Review of Research in Open and Distributed Learning, 12(3), 19-38. doi:10.19173/irrodl.v12i3.882

Kurzweil, M. (2018). Alternative postsecondary pathways: What we know, what we don't know, and why it matters. Change: The Magazine of Higher Learning, 50(3-4), 154-157. doi:10.1080/00091383.2018.1509654

Lave, J., \& Wenger, E. (1991). Situated learning: Legitimate peripheral participation. Cambridge, MA: Cambridge University Press. doi:10.1017/CBO9780511815355

Lee, D., Watson, S. L., \& Watson, W. R. (2019). Systematic literature review on self-regulated learning in massive open online courses. Australasian Journal of Educational Technology, 35(1), 28-41. doi:10.14742/ajet.3749

Lincoln, Y. S., \& Guba, E. G. (1985). Establishing trustworthiness. In Naturalistic inquiry (pp. 289-331). http://doi.org/10.1177/1473325006070288

Littlejohn, A., Hood, N., Milligan, C., \& Mustain, P. (2016). Learning in MOOCs: Motivations and self-regulated learning. The Internet and Higher Education, 29, 40-48

Liu, M., Kang, J., \& McKelroy, E. (2015). Examining learners' perspective of taking a MOOC: Reasons, excitement, and perception of usefulness. Educational Media International, 52(2), 129-146. doi:10.1080/09523987.2015.1053289

Lowenthal, P., \& Hodges, C. (2015). In search of quality: Using Quality Matters to analyze the quality of massive, open, online courses (MOOCs). The International Review of Research in Open and Distributed Learning, 16(5). doi:10.19173/irrodl.v16i5.2348

Lowenthal, P., Snelson, C., \& Perkins, R. (2018). Teaching massive, open, online, courses (MOOCs): Tales from the front line. International Review of Research in Open and Distributed Learning, 19(3). doi:10.19173/irrodl.v19i3.3505 
Margaryan, A., Bianco, M., \& Littlejohn, A. (2015). Instructional quality of massive open online courses (MOOCs). Computers \& Education, 80, 77-83.

doi:10.1016/j.compedu.2014.08.005

McMahon, M. (1997). Social constructivism and the World Wide Web-A paradigm for learning. Paper presented at ASCILITE conference, Perth, Australia, p. 327.

Milligan, C., Littlejohn, A., \& Margaryan, A. (2013). Patterns of engagement in connectivist MOOCs. MERLOT Journal of Online Learning and Teaching, 9(2). doi:10.1007/s12186010-9041-6

Najafi, H., Rolheiser, C., Harrison, L., \& Håklev, S. (2015). University of Toronto instructors' experiences with developing MOOCs. The International Review of Research in Open and Distributed Learning, 16(3). doi:10.19173/irrodl.v16i3.2073

Onah, D. F., Sinclair, J., \& Boyatt, R. (2014). Dropout rates of massive open online courses: Behavioural patterns. EDULEARN14 Proceedings, 5825-5834. doi:10.13140/RG.2.1.2402.0009

Park, Y., Jung, I., \& Reeves, T. C. (2015). Learning from MOOCs: A qualitative case study from the learners' perspectives. Educational Media International, 52(2), 72-87. doi:10.1080/09523987.2015.1053286

Palvia, S., Aeron, P., Gupta, P., Mahapatra, D., Parida, R., Rosner, R., \& Sindhi, S. (2018). Online education: Worldwide status, challenges, trends, and implications. Journal of Global Information Technology Management, 21(4), 233-241. doi:10.1080/1097198X.2018.1542262

Pintrich, P. R. (2000). The role of goal orientation in self-regulated learning, In M. Boekaerts, P. R. Pintrich, \& M. Zeidner (Eds.), Handbook of self-regulation (pp. 451-502). San Diego, CA: Academic. doi:10.1016/B978-012109890-2/50043-3

Reich, J., \& Ruipérez-Valiente, J. A. (2019). The MOOC pivot. Science, 363(6423), 130-131. doi:10.1126/science.aav7958

Ross, J., Sinclair, C., Knox, J., Bayne, S., \& Macleod, H. (2014). Teacher experiences and academic identity: The missing components of MOOC pedagogy. Journal of Online Learning and Teaching, 10(1), 57-69. doi:10.1080/02680930701754047

Saldana, J. (2013). The coding manual for qualitative researchers (2nd ed.). Thousand Oaks, CA: Sage.

Seaman, J. E., Allen, I. E., \& Seaman, J. (2018). Grade increase: Tracking distance education in the United States. Babson Survey Research Group.

Shearer, R. L. (2012). Theory to practice in instructional design. In M. G. Moore (Ed.), Handbook of distance education. Retrieved from https://ebookcentral.proquest.com

Siemens, G. (2012). MOOCs are really a platform. eLearnspace.

Strauss, A., \& Corbin, J. (1994). Grounded theory methodology. Handbook of Qualitative Research, 17, 273-85. 
Suen, H. K. (2014). Peer assessment for massive open online courses (MOOCs). The International Review of Research in Open and Distributed Learning, 15(3). doi:10.19173/irrodl.v15i3.1680

Toven-Lindsey, B., Rhoads, R. A., \& Lozano, J. B. (2015). Virtually unlimited classrooms: Pedagogical practices in massive open online courses. The Internet and Higher Education, 24, 1-12. doi:0.1016/j.iheduc.2014.07.001

Veletsianos, G., \& Shepherdson, P. (2016). A systematic analysis and synthesis of the empirical MOOC literature published in 2013-2015. International Review of Research in Open and Distance Learning, 17, 198-221. doi:10.19173/irrodl.v17i2.2448

Vygotsky, L. S. (1978). Mind in society: The development of higher psychological processes. doi:10.12691/education-5-5-8

Walji, S., Deacon, A., Small, J., \& Czerniewicz, L. (2016). Learning through engagement: MOOCs as an emergent form of provision. Distance Education, 37(2), 208-223. doi:10.1080/01587919.2016.1184400

Xing, W. (2019). Exploring the influences of MOOC design features on student performance and persistence. Distance Education, 40(1), 98-113, doi:10.1080/01587919.2018.1553560

Yengin, I., Karahoca, A., \& Karahoca, D. (2011). E-learning success model for instructors' satisfactions in perspective of interaction and usability outcomes. Procedia Computer Science, 3, 1396-1403. doi:10.1016/j.procs.2011.01.021

Yin, R. K. (2014). Case study research and applications: Design and methods. SAGE.

Yousef, A. M. F., Chatti, M. A., Schroeder, U., Wosnitza, M., \& Jakobs, H. (2014). A review of the state-of-the-art. Proceedings of CSEDU, 9-20.

Yuan, L., \& Powell, S. (2013). MOOCs and open education: Implications for higher education (White paper). London: JISC CETIS. doi:10.13140/2.1.5072.8320

Zelinski, M., Hicks, N. M., Wang, S., Douglas, K. A., Bermel, P., Diefes-Dux, H. A., \& Madhavan, K. (2017). Instructor outcomes of teaching a STEM MOOC. In Frontiers in Education Conference (FIE), 1-7. IEEE. doi:0.1109/FIE.2017.8190590

Zheng, S., Wisniewski, P., Rosson, M. B., \& Carroll, J. M. (2016). Ask the instructors: Motivations and challenges of teaching massive open online courses. In Proceedings of the 19th ACM Conference on Computer-Supported Cooperative Work \& Social Computing, 206-221. New York, NY: Association for Computing Machinery (ACM). doi:10.1145/2818048.2820082

Zutshi, S., O'Hare, S., \& Rodafinos, A. (2013). Experiences in MOOCs: The perspective of students. American Journal of Distance Education, 27(4), 218-227. 


\section{Appendix A}

\section{Semistructured qualitative interview protocol}

Participant name: Date:

Interview start time: Stop time:

\section{Interview Protocol:}

- How do you define quality learning?

- Given your specific topic or subject matter, how do you measure or verify learning?

- From your perspective as the professor, how do you determine that quality learning has occurred among learners in your MOOC?

- (If needed for further clarification) What have you seen from learners in your course that you would consider evidence of their learning?

- What aspects or characteristics of MOOCs do you think contribute to or promote quality learning?

- Are there specific steps or activities in your MOOC that where you felt were conducive to quality learning? Why or why not?

- The MOOC platform that you used is designed to encourage social interaction to promote learning. From your perspective, do you think that this has an impact on the learning that occurs in your MOOC? Why or why not?

- How does the learning in your MOOC compare with other courses that you have taught?

- What limitations to learning, if any, do you see as being inherent in your MOOC?

- Could you describe or share your overall experience having taught a MOOC?

- What impact, if any, has it had on your perspective as a professor?

- What impact, if any, has it had on your perceptions of quality learning?

- (If time at end) Do you think that there is anything that could be implemented that would improve learning that takes place in the moves that you've taught? 


\section{Appendix B}

Quality Learning

\section{A Priori Codes}

\begin{tabular}{|l|l|l|}
\hline \multicolumn{1}{|c|}{ Code } & \multicolumn{1}{|c|}{ Example/Definition } & \multicolumn{1}{c|}{ Cited Source(s) } \\
\hline $\begin{array}{l}\text { Definition of quality } \\
\text { online learning } \\
\text { (QUAL_Def) }\end{array}$ & $\begin{array}{l}\text { Definitions given by the } \\
\text { participant on what a quality } \\
\text { learning is or what it looks like }\end{array}$ & $\begin{array}{l}\text { Kim (2001); Lave \& Wenger } \\
\text { (1991); Vygotsky (1978) }\end{array}$ \\
\hline $\begin{array}{l}\text { Determining or measuring } \\
\text { quality learning in any } \\
\text { course } \\
\text { (QUAL_Measure_Gen) }\end{array}$ & $\begin{array}{l}\text { Verbal examples of determining } \\
\text { or measuring quality learning in } \\
\text { any course or learning } \\
\text { environment }\end{array}$ & $\begin{array}{l}\text { Suen (2014); Toven-Lindsey, } \\
\text { Rhoads, \& Lozano, (2015) }\end{array}$ \\
\hline $\begin{array}{l}\text { Example(s) of quality } \\
\text { learning in MOOC } \\
\text { (QUAL_Examp_MOOC) }\end{array}$ & $\begin{array}{l}\text { Verbal examples provided by the } \\
\text { participant illustrating principles } \\
\text { of quality learning in MOOC(s) }\end{array}$ & $\begin{array}{l}\text { Walji, Deacon, Small, \& } \\
\text { Czerniewicz (2016) }\end{array}$ \\
\hline $\begin{array}{l}\text { Determining or measuring } \\
\text { quality learning in MOOC } \\
\text { (QUAL_Measure_MOOC) }\end{array}$ & $\begin{array}{l}\text { Verbal examples of determining } \\
\text { or measuring quality learning in } \\
\text { MOOC(s) }\end{array}$ & $\begin{array}{l}\text { Toven-Lindsey, Rhoads, \& } \\
\text { Lozano, (2015) }\end{array}$ \\
\hline
\end{tabular}

\section{Social Constructivism/Social Learning}

\begin{tabular}{|l|l|l|}
\hline \multicolumn{1}{|c|}{ Code } & \multicolumn{1}{|c|}{ Example } & \multicolumn{1}{c|}{ Cited Source(s) } \\
\hline $\begin{array}{l}\text { Examples of evidence of } \\
\text { social constructivism } \\
\text { (SocL_Examp) }\end{array}$ & $\begin{array}{l}\text { Verbal examples from participant } \\
\text { in which he/she saw evidence of } \\
\text { social constructivism/learning } \\
\text { occur in MOOC }\end{array}$ & $\begin{array}{l}\text { Herrington \& Oliver (1999); } \\
\text { Lave \& Wenger (1991); } \\
\text { Toven-Lindsey, } \\
\text { Rhoads, \& Lozano (2015) }\end{array}$ \\
\hline $\begin{array}{l}\text { Dialogue/Discussion } \\
\text { (SocL_Dial_Disc) }\end{array}$ & $\begin{array}{l}\text { Verbal example that indicates } \\
\text { reference to dialogue or } \\
\text { discussions among } \\
\text { learners/instructors in the MOOC }\end{array}$ & $\begin{array}{l}\text { Toven-Lindsey, Rhoads, \& } \\
\text { Lozano (2015) }\end{array}$ \\
\hline
\end{tabular}




\begin{tabular}{|l|l|l|}
\hline $\begin{array}{l}\text { Collaboration } \\
\text { SocL_Collab) }\end{array}$ & $\begin{array}{l}\text { Verbal example that indicates } \\
\text { reference to collaboration among } \\
\text { learners in the MOOC }\end{array}$ & $\begin{array}{l}\text { Toven-Lindsey, Rhoads, \& } \\
\text { Lozano (2015) }\end{array}$ \\
\hline $\begin{array}{l}\text { Negotiation of meaning } \\
\text { (SocL_Negot) }\end{array}$ & $\begin{array}{l}\text { Verbal example that indicates } \\
\text { reference to negotiation of } \\
\text { meaning among learners in the } \\
\text { MOOC }\end{array}$ & $\begin{array}{l}\text { Toven-Lindsey, Rhoads, \& } \\
\text { Lozano (2015) }\end{array}$ \\
\hline $\begin{array}{l}\text { Interaction } \\
\text { (SocL_Interact) }\end{array}$ & $\begin{array}{l}\text { Verbal example that indicates } \\
\text { reference to any other interaction } \\
\text { among learners in the MOOC }\end{array}$ & $\begin{array}{l}\text { Toven-Lindsey, Rhoads, \& } \\
\text { Lozano (2015) }\end{array}$ \\
\hline
\end{tabular}

\section{Relationship Between Social Learning and Quality Learning in MOOC}

\begin{tabular}{|l|l|l|}
\hline \multicolumn{1}{|c|}{ Code } & \multicolumn{1}{|c|}{ Example } & \multicolumn{1}{c|}{ Cited Source(s) } \\
\hline $\begin{array}{l}\text { Factors/characteristics that } \\
\text { contribute to quality } \\
\text { learning in MOOC } \\
\text { (QUAL_Contrib_MOOC) }\end{array}$ & $\begin{array}{l}\text { Verbal example of how a } \\
\text { particular factor of MOOCs can } \\
\text { influence the quality of learning }\end{array}$ & $\begin{array}{l}\text { Arbaugh \& Benbunan-Fich } \\
\text { 2006) }\end{array}$ \\
\hline $\begin{array}{l}\text { Intentionality of use of } \\
\text { social learning in MOOC } \\
\text { (SocL_Intent) }\end{array}$ & $\begin{array}{l}\text { Intentional use or application of } \\
\text { Social Learning in MOOC }\end{array}$ & $\begin{array}{l}\text { Gasevic, Kovanovic, } \\
\text { Joksimovic, \& Siemens (2014) }\end{array}$ \\
\hline $\begin{array}{l}\text { Examples of social } \\
\text { learning in MOOC } \\
\text { (SocL_Examp_MOOC) }\end{array}$ & $\begin{array}{l}\text { Verbal examples provided by the } \\
\text { participant illustrating principles } \\
\text { or evidence of social learning in } \\
\text { MOOC(s) }\end{array}$ & $\begin{array}{l}\text { Toven-Lindsey, Rhoads, \& } \\
\text { Lozano (2015) }\end{array}$ \\
\hline $\begin{array}{l}\text { Social learning impact on } \\
\text { quality learning in MOOC } \\
\text { (SocL_Effect_QUAL) }\end{array}$ & $\begin{array}{l}\text { Verbal examples of how social } \\
\text { learning impacted the quality of } \\
\text { learning in MOOC(s) }\end{array}$ & $\begin{array}{l}\text { Toven-Lindsey, Rhoads, \& } \\
\text { Lozano (2015) }\end{array}$ \\
\hline
\end{tabular}




\section{Perception}

\begin{tabular}{|l|l|l|}
\hline \multicolumn{1}{|c|}{ Code } & \multicolumn{1}{|c|}{ Example } & \\
\hline $\begin{array}{l}\text { Teaching a MOOC's } \\
\text { impact on professor's } \\
\text { perspective } \\
\text { (PERSP_Change) }\end{array}$ & $\begin{array}{l}\text { Insight given by participant on } \\
\text { how their previous perception of } \\
\text { quality learning changed after } \\
\text { teaching MOOC }\end{array}$ & $\begin{array}{l}\text { Evans \& Myrick (2015); Deng, } \\
\text { Benckendorff, \& Gannaway } \\
\text { (2017); Haavind \& Sistek- } \\
\text { Chandler (2015); Najafi, } \\
\text { Rolheiser, Harrison, \& Håklev } \\
\text { (2015); Zelinski, Hicks, Wang, } \\
\text { Douglas, Bermel, Diefes-Dux, } \\
\text { \& Madhavan (2017); Zheng, } \\
\text { Wisniewski, Rosson, \& Carroll } \\
\text { (2016) }\end{array}$ \\
& & $\begin{array}{l}\text { Evans \& Myrick (2015); } \\
\text { Haavind \& Sistek-Chandler } \\
\text { (2015); Najafi, Rolheiser, } \\
\text { Harrison, \& Håklev (2015); } \\
\text { Zelinski, Hicks, Wang, } \\
\text { Douglas, Bermel, Diefes-Dux, } \\
\text { \& Madhavan (2017) }\end{array}$ \\
\hline $\begin{array}{l}\text { Strategy recommendations } \\
\text { for improvement } \\
\text { (IMPROVE_Recommend) }\end{array}$ & $\begin{array}{l}\text { Recommendations by participants } \\
\text { on improving quality learning in } \\
\text { MOOCs }\end{array}$ & \multicolumn{2}{|l}{} \\
& &
\end{tabular}

